\title{
LEGAL TERMINOLOGY PHENOMENON IN THE CONTEXT OF MODERN LEGAL SYSTEM EVOLUTION
}

\author{
Vladislav Yu. Turanin ${ }^{1 *}$, Evgenii E. Tonkov ${ }^{2}$, Irina A. Kuprieva ${ }^{3}$, Lyubov A. Pozharova ${ }^{4}$, Neonila A. Turanina ${ }^{5}$ \\ ${ }^{1,2,4}$ Belgorod State University, 85 Pobedy St., Belgorod, 308015, Russia, ${ }^{3}$ Institute of International Law and Economy \\ named after A.S. Griboedov, 21Entuziastov Highway, Moscow, 11102, Russia, ${ }^{5}$ Belgorod State Institute of Arts and Cul- \\ ture, 7 Koroleva St., Belgorod, 308033, Russia. \\ E-mail: *turanin@mail.ru
}

\section{Article History: Received on $25^{\text {th }}$ July 2019, Revised on $01^{\text {st }}$ September 2019, Published on $12^{\text {th }}$ October 2019}

\begin{abstract}
Purpose: This study aimed to determine the legal terminology phenomenon in the context of modern legal system evolution.

Methodology: In the present research different general scientific methods and ways of logical cognition are used. Analysis and synthesis methods were applied for the studying purpose of legal terminology entity and also its conversion to a legal terminological system.

Result: On the basis of the Russian legal system periodization stages of the legal terminological system forming were marked out. In the present context the attention to logical and legal circumstances that directly influence emergence of legal terms is paid. These terms serve as premises for legal terminological systems appearing: need to express an entity of the new legal phenomenon or process; need for its language denomination, visualization, and, respectively, systematic conversion of a legal idea to legal standard. Evolution features of a legal terminological system in terms of its consecutive change occurring under the influence of two factors are investigated: terminological continuity and differentiation.
\end{abstract}

Applications: This research can be used for the universities, teachers and education students.

Novelty/Originality: In this research, the model of the legal terminology phenomenon in the context of modern legal system evolution is presented in a comprehensive and complete manner.

Keywords: legal terminology, the legal system, legal terminological system, legal rules, laws and regulations, evolution, continuity, differentiation.

\section{INTRODUCTION}

The legal terminology is of particular importance for legal acts formulation and for modern legal system development. The preparation of any legal act is firstly connected with legal terms using reflecting the maintenance of the corresponding concept that designates the legal phenomena and processes. The use of terms is always the most effective way of information delivery that is contained in legal rules to each specific addressee.

The exact and explicit use of legal terms plays an important role in the prevention of legal rules deformation also. Mistakes in legal terms use in legal acts can be the reason for infringement of rights and freedoms of citizens and for political and legal collisions prerequisites.

The real knowledge of the legal phenomena and processes entity is possible by means of the deep legal concepts analysis expressed by legal terms; it also includes features studying in the context of right. The legal term is the visible object written in the legal source, has specific legal meaning, indirectly by means of a legal concept, and reflects the legal phenomenon or process entity. Each user while facing the certain term fixed in this or that law source finds out new research possibilities find right common features. It is possible to say that the legal terminology is something that helps to study out the entity of legal system. So the legal terminology, also as well as the legal concepts expressed with its help, and, respectively, the explained legal phenomena and processes, represents a full informative part of the legal system. It is an irreplaceable component of legal reality.

\section{METHODS}

In present research different general scientific methods and ways of logical cognition are used. Analysis and synthesis methods were applied for the studying purpose of legal terminology entity and also its conversion to a legal terminological system. Application of legalistic, historical, comparative and legal methods allowed carrying out the analysis of legal terminological system formation process in conditions of legal system evolution. The system, structural, functional, formal and logical approaches were used for the identification of system and logical features of legal terminology functioning in the context of modern legal system development.

\section{DISCUSSION AND RESULTS}

The legal terminology research allows looking widely at its importance in the legal system theory, on its role in modern Russian legal system development. Now the legal terminology problems theoretical research is traditionally conducted within the legal methods in interrelation with other aspects of the analysis of form and content of laws and other regula- 
tions. At the same time, in our opinion, the settled perception of legal terminology only as means of the legal method reflects the narrow approach to its meaning for the legal system, insufficient for an effective solution of the existing terminological problems which are present at the official text. The legal terminology has to be considered widely, as an independent all-legal phenomenon and to be perceived as the integral element of legal reality. Let's say a little metaphorically that the legal terminology has the same value for the legal system as, for example, clothes have for people, as it is impossible to live without it in the modern society.

The legal terminology is characterized by system properties. In the philosophical sense, according to one of the founders of the general theory of systems Ludwig von Bertalanffy, the system is a "complex of the elements which are in interaction" (Kong, Hoi. 2010; Kremin A.E., Gulin K.A. 2017). We believe that the legal terminological system can be presented as structurally ordered set of the terms used in legal language, existing in interrelation and interdependence cyclic in its development.

Each legal phenomenon or process appearing as its conceptual basis expressed by means of legal terms. Adolf Wach wrote that "as a child does not want to have a new name ... the same it is about new legal terms creation. This term should make content distinct; also it should express concept entity and legal value if it is possible. The coin should have original stamping and size and should correspond to lettering. In this case it becomes important, irreplaceable supplement for our image" (Rybakov V.A. 2015; Solovyev S.G. 2012).

Timelines of legal terminological system formation correspond to the periods of Russian legal system development. It may be overviewed on the example of Russian legislation terminological system formation which formation cyclicality directly depends on historical stages of domestic legal system development. While features research of Russian legislation terminology formation in time, on the basis of the various points of view analysis, we considered as a basis an idea of V.N. Sinukov who allocated five periods of legal system development according to its "state" changes:

1. The Russian legal system formation that corresponds to the Old Russian territorial state (the 9-13th centuries);

2. The legal system of the Moscow state (the 14-17th centuries);

3. The legal system of the Russian Empire (18 - the beginning of the 20th centuries);

4. The Soviet legal system (the 20-80s of the 20th century);

5. The Post-Soviet legal system of the Russian Federation (the end of the 20th century) (Werner Menski. 2006; Hojati, M., Rezaei, F., \& Iravani, M. R. 2014).

The most significant stages of legal terminology formation correspond to the allocated periods of the legal system development. Therefore we believe that this periodization, despite its relativity (as for any periodization) can be used also in relation to the general legal terminological system. In our opinion, the last development stage could be called modern instead of Post-Soviet.

Besides we would like to note that the Russian legal terminological system formation needs to be connected with written sources of law appearing. Moreover, the term has to be visualized, defined, its system characteristics should be accurately overviewed. That's why while making periodization of the general legal terminological system it is important to connect it with such sources.

Based on the foregoing it is possible to name five periods of legal terminological system development. It is the legal terminological system fixed in written sources of law:

- The Old Russian territorial state (the 9-13th centuries);

- The Moscow state (the 14-17th centuries);

- The Russian Empire (18 - the beginning of the 20th centuries);

- The USSR (20-80s of the 20th century);

- Modern Russia (the end of the 20th century - the present time).

In the context of the modern Russian legal system evolution it is important to establish logical and legal circumstances that directly influence on appearing of concepts and terms expressing them, so, it is a prerequisite for legal terminological system appearing. In our opinion it is possible to make out two following circumstances:

- Need to express an entity of the new legal phenomenon or process (Shelton, D. (Ed.). (2003));

- Need for its language designation, visualization and systematic conversion of legal thought to rule of law respectively.

The interrelation of the legal phenomena and processes with concepts and terms appearing existed all the time. For example, during the Old Russian territorial state formation there was a need to define types of crime, and in the Russkaia Pravda (book of legal rules the Old Russian state) the corresponding terminology appeared: "ubit" (murder), "tatba" (theft), "vynut mech" (assault to murder). There was a need to describe hereditary relations. Such terms as "rukopisani" (will), 
"otmorshina" (hereditary succession), "prikaznoe" (testamentary succession), "zhivot" (movable things), "otchina" (chose transitory) were written in the text of the Pskov court document (regulatory legal act that regulated civil law relations in the Old Russian state).

In written sources of law of the Moscow state for the description of the new legal phenomena and processes such terms as "witnesses" (Law Book of 1497), "votchina"(ancestral lands) (Law Book of 1550), "chapman", "bill of sale" (Council code of 1649) appeared.

The legal terminological system formation fixed in written sources of law of the Russian Empire is characterized by appearing of such terms as, for example, "real thing", "movable property" (Peter's the First decree on primogeniture of 1714), "property" (The codebook of the Russian Empire).

During the Soviet period in various legal sources the phenomena and processes terms of that era appeared: "People's Court" (The Civil Code of the Russian SFSR of 1922), "crime against state" (The Criminal code of RSFSR of 1922), "personal ownership" (The Constitutional Document of the USSR of 1936), "non-labour income" (The Civil Code of the Russian SFSR of 1964) (Sultanbekova, Z., Yergobek, K., Atemova, K., \& Koshenova, T. 2018).

In this regard, the legal terminology fixed in written sources of the modern law represents no more than next cycle of legal terminological system development which is also connected with public relations updating. Also implementation in various legal acts of such new terms as "commercial bribery", "illegal enterprise" (The Criminal code of the Russian Federation), "commercial representation office" (The Civil Code of the Russian Federation), etc. is a consequence of it.

The issue of legal terms definition, definitions appearing in various legal sources occurs to be very interesting in the context of modern legal system evolution. At the same time, for example, Gaudemet E. notes that definitions "can slow down any legal thought development and limit hard legal rules interpretation" (Matandare, M. A. 2018). Carbonnier J. believes, "definitions are not the legislator but the doctrine deal, for the legislator it is not fit" (6, p. 67). In our point of view, modern legal acts are impossible without definitions. That's why term definitions must be and are also needed in them. Anecdotal evidence suggests "with time each term in legal context has its special field of meanings that is different from the everyday speech" (Nazoktabar, H., \& Tohidi, G. 2014). In other words, terms become legal by means of definitions, and it must be borne in mind.

Legal terminological system evolution, in our point of view, needs to be overviewed as the process of consecutive change that happens under the influence of two factors: terminological continuity and differentiation.

In the context of law development, N. Nenovski distinguishes two types of continuity "in vertical direction" (in time) and "in horizontal direction" (in space). In his opinion continuity in time means that elements are kept the same while the change to new qualitative conditions of the same national legal system. Continuity in space takes into consideration past legal experience of other states (Kuznetsova, E. 2019). This concept can be applied to a legal terminological system (Sinclair, M. B. (1993)).

So, terminological continuity "in vertical direction" means terms saving while changing from one legal terminological system (a subsystem within the general system) to another within development of the Russian legal language, and continuity "in horizontal direction" means that the elements used in legal terminology are perceived by the domestic terminological system of by means of reception. At the same time "in vertical direction" continuity has to correspond to "in horizontal direction" continuity. Introducing the new borrowed legal terms, it is possible to modernize the existing terminological system, and to create an additional element in it additional (that can be excess). Montesquieu Ch. fairly noticed that "laws should not be farfetched at all: they are done for people with middle brain" (Lima, A., Mendes, D., \& Paiva, S. 2018). That's why it's important to be careful while borrowing terms into the legal text (Ewald, W. (1995)).

However, there are examples when legal acts draftspersons initially had a task to prepare the document only for a certain part of society that has the corresponding professional education. For example, draftspersons of the German Civil Code of 1900 consciously wanted to "to draft the civil popular code not available to every person, but for lawyers as an especially legal work ...". While preparing the modern Civil code of the Netherlands of 1992 the same model was used: its main ideologist E. Meyers had a goal to prepare code for scientists, but not the code for everyone. We would like to notice that this idea was carried out and the Civil code of the Netherlands is really very difficult and abstract. Of course, this approach that is called "German" has desert right of existence. At the same time in our opinion it has to be hardly much-in-demand for Russian lawmaking (Torres, G. (1990).).

Another factor of legal terminological system evolution is terminological differentiation. Taking into account evolution features of any new system it is possible to reveal such trends: inside the system, there is the difference between qualitative and identical elements (elements that make the system) that becomes stronger hereafter, it means that differentiation happens. It is peculiar for the legal terminological system also which elements differentiation is based on various models of legal terms application. So, for example, due to the fact of new branches of law formation in the Russian legal system, new terminology is formed step-by-step and taken to the relevant legal acts. Various terminological ranks, devices are established. New connections not existing before develop between them. It, finally, promotes branch terminological interpenetration. It is useful to highlight in this regard that terminological differentiation is the process of establishment and further 
strengthening of difference between elements of a legal terminological system based on a branch legal terminology and various terminological ranks and devices formation (Wise, E. M. (1990).).

\section{CONCLUSION}

Modern legal terminological system formation is going very fast, reflecting the growth rates the general trends of modern legal terminological system development connected with the annual increase in number of legal acts. Most likely, it is necessary to speak about correctness of such high-speed way with some reservation as the quantity of the introduced terminological innovations not always demonstrates increase, or at least preservation, qualities of the legal text. It is logical to assume that legal terminological system formation has to go on an evolution basis: subject to time, but taking into account already-existing experience.

\section{CONFLICT OF INTEREST}

The authors confirm that the information provided in the article does not contain a conflict of interest.

\section{ACKNOWLEDGMENT}

This article is supported by the financial support of the Belgorod State National Research University within the scientific project of 2018-2019. "The state creating". The key initiative: "The state creating: influence of a legal terminology on the modern Russian legislation development ".

\section{REFERENCES}

1. Kong, Hoi. (2010). "Something to Talk About: Regulation and Justification in Canadian Municipal Law." Osgoode Hall Law Journal 48.3/4(2010) : 499-541 // http://digitalcommons.osgoode.yorku.ca/ohlj/vol48/iss3/4

2. Kremin A.E., Gulin K.A. (2017). Managing the functioning of small business at the municipal level as a driver of regional economic development // Economic and Social Changes: Facts, Trends, Forecast, 2017, vol. 10, no. 4, pp. 94-110. https://doi.org/10.15838/esc.2017.4.52.5

3. Rybakov V.A. (2015). Pravotvorchestvo v perechodnyj period razvitia prava// Yuridicheskaya technika. 2015. № 9. p. 653-656.

4. Solovyev S.G. (2012). Ponyatie predmeta prav. reg i ego vsaimosvyaz's drugimi yuridicheskimi kategoriyami// Vestnik Permskogo Universiteta, 2012. № 1 (15). pp.47-48.

5. Werner Menski. (2006). Comparative Law in global context. The legal systems of Asia and Africa ( 2006). https://doi.org/10.1017/CBO9780511606687

6. Hojati, M., Rezaei, F., \& Iravani, M. R. (2014). Study the Effects of Cognitive and Metacognitive Learning Strategies to Increase Student Motivation and Probation of Sama Vocational Schools Probation Students of Najaf Abad Branches in School Year 2013-2014, UCT Journal of Management and Accounting Studies, 2(2): 35-40

7. Sultanbekova, Z., Yergobek, K., Atemova, K., \& Koshenova, T. (2018). Role of Works of Kazakh Writer Dulat Issabekov in Modern National. Opción, 34, 110-132.

8. Matandare, M. A. (2018). Botswana Unemployment Rate Trends by Gender: Relative Analysis with Upper Middle Income Southern African Countries (2000-2016). Dutch Journal of Finance and Management, 2(2), 04. https://doi.org/10.20897/djfm/3837

9. Nazoktabar, H., \& Tohidi, G. (2014). Shanty Town and Socio-Cultural Problems in Sari City, Iran, UCT Journal of Social Sciences and Humanities Research, 2(2): 29-31.

10. Kuznetsova, E. (2019). Probabilistic Ideas and Methods in Undergraduate Mathematics: Axiological Aspects. International Electronic Journal of Mathematics Education, 14(2), 363-373. https://doi.org/10.29333/iejme/5720

11. Lima, A., Mendes, D., \& Paiva, S. (2018). Outdoor Navigation Systems to Promote Urban Mobility to Aid Visually Impaired People. Journal of Information Systems Engineering \& Management, 3(2), 14. https://doi.org/10.20897/jisem.201814

12. Torres, G. (1990). Critical race theory: The decline of the universalist ideal and the hope of plural justice--some observations and questions of an emerging phenomenon. Minn. L. Rev., 75, 993.

13. Ewald, W. (1995). Comparative jurisprudence (II): the logic of legal transplants. The American Journal of Comparative Law, 43(4), 489-510. https://doi.org/10.2307/840604

14. Shelton, D. (Ed.). (2003). Commitment and compliance: The role of non-binding norms in the international legal system. Oxford University Press on Demand.

15. Wise, E. M. (1990). The transplant of legal patterns. The American Journal of Comparative Law, 1-22. https://doi.org/10.2307/840531

16. Sinclair, M. B. (1993). Evolution in Law: Second Thoughts. U. Det. Mercy L. Rev., 71, 31.

17. Meyer, J. W., \& Jepperson, R. L. (2000). The 'actors' of modern society: The cultural construction of social agency. Sociological theory, 18(1), 100-120. https://doi.org/10.1111/0735-2751.00090

18. Hodgson, G. M. (2015). Conceptualizing capitalism: Institutions, evolution, future. University of Chicago Press. https://doi.org/10.7208/chicago/9780226168142.001.0001 
Humanities \& Social Sciences Reviews elSSN: 2395-6518, Vol 7, No 4, 2019, pp 1291-1295 https://doi.org/10.18510/hssr.2019.74178

19. Rehbinder, M. (1970). Status, contract, and the welfare state. Stan. L. Rev., 23, 941. https://doi.org/10.2307/1227894

20. Posner, R. A. (1998). The problematics of moral and legal theory. Harvard Law Review, 1637-1717. https://doi.org/10.2307/1342477

21. Mattei, U. (1997). Comparative law and economics. University of Michigan Press. https://doi.org/10.3998/mpub.11209 